\title{
The Perceptions of Middle - Aged About Physical Activity Related Incident Prediabetes
}

\author{
Sumandar, Rohmi Fadhli, Muhammad Firdaus \\ Al Insyirah School of Health Sciences Parit Indah St. 38 Pekanbaru, Indonesia \\ sumandar.05mangiri@gmail.com
}

\begin{abstract}
Diabetes mellitus is a metabolic disorder characterized by the presence of hyperglycemia due to defective insulin secretion, defective insulin action or both. Diabetes mellitus symptom does not occur suddenly, it takes a long process. Generally, it begin with prediabetes. Pre-diabetes is a condition where blood glucose content is above normal, but it does not measure up to the criteria of diabetes mellitus yet. According to the American Diabetes Association, screening should be done in 45-59 years. State they have a high risk of chronic illness and low health status caused by bad behaviors such as physical activity. The study aim was to determine correlation perceptions of middle-aged about physical activity toward incident prediabetes. The Sample of 54 participants selected by using cluster sampling and cross-sectional method. Bivariate analysis data was by using chi-square analysis. There were $29,6 \%$ middle-aged had been incident prediabetes. The conclusion of this research there was perceptions relation between perceptions with incident pre-diabetes (p-value 0,$002 ;$ OR; 0,118 ). This study recommends to community health nurse in quality improvement such as attending workshop, training, exchange of nurse, changing the design education and health promotion, Focus group discussion with them. Service excellent will be reflected to decrease prediabetes, so that degree of health and maintain can be achieved. Further can build post health service.
\end{abstract}

Keywords: Physical Activity, Incident Prediabetes, Perceptions, Middle-Aged 


\section{STRADA Jurnal Ilmiah Kesehatan}

DOI: $10.30994 /$ sjik.v8i2.205

ISSN: 2252-3847 (print); 2614-350X (online)

Vol.8 No.2. November 2019. Page.101-107

\section{BACKGROUND}

The result of Indonesian population census in 2010 explained that Indonesia has 23.641.326 inhabitant(BPS, 2014). From these data, it was found that the population included in the elderly category (45 years and over) was about $22 \%$ of the total population of Indonesia.

Aging is a fade out proccess of network ability to repair itself or to replace and maintain its normal function so that it can not withstand against infections and changes that be suffered by individuals related to biological, psychological, social, and spiritual factor.The rate of these changes are different for each individual (CONTANTINIDES, 1994; in Nugroho,2007). Metabolism disorders, such as Diabetes Mellitus is one of the health problem toward middle aged (45 years and over) (Kontjoro, 2002; Aspiani, 2014). Prediabetes checkup is recommended at 45 years old or over (Of \& Carediabetes, 2015).

It can be concluded that a risky of health condition in middle age is Diabetes Mellitus. This desease does not occure suddenly, but has a long time process and commonly it begin than normal but has not measure up to Diabetes Mellitus criteria by prediabetes. Prediabetes is a condition from individual that has glucose levels higher (Panesar and Hons, 2013, Rumahorbo 2014).

Diagnosis of prediabetes includes HBA1c 5.7 - 6.4\%, fasting blood glucose levels 100-125 $\mathrm{mg} / \mathrm{dl}$, and blood glucose levels 2 hours after meals 140-199 mg/dl gnosis of prediabetes includes HBA1c 5.7 - 6.4\%, fasting blood glucose levels $100-125 \mathrm{mg} / \mathrm{dl}$, and blood glucose levels 2 hours after meals 140-199 mg/dl (Care, 2014). Individuals who have prediabetes often unaware or even show clinical signs and symptoms. Pre-diabetes can increase become. Type 2 of Diabetes Mellitus as much as 2-10 times, moreover in certain populations, this risk can be higher

Prevalence of prediabetes in Indonesia was about $10 \%$ (Pradana Soewondo, 2011). Prediabetes incidence in middle-aged was about 47.4\% (Sovia, Rekawati, \& Kuntarti, 2013). Based on these researcher's study, it is can be concluded that the incidence of prediabetes has been increased.

Individuals health that influenced by behavior and lifestyle was about 50\% (CDC, 2006; Bremer \&amp; Synder, 2014). Therefor, the risk of diseases caused by prediabetes can be prevented by improving healthy living behaviors. Some of behavioral modification in individual prediabetes were by doing physical activity, dietary management, selection of the right sleeping pills, and body weight management (Panesar and Hons, 2013).

Healthy lifestyle such as doing physical exercise regularly and a balanced diet can be prevented or reduced diabetes at-risk population(Ramachandran, 2012). Along with this problems a significant effort is needed so that the health of middle-aged can increase. One of the effort is by doing prevention.

A positive perceptions of prevention efforts in diseases incidence also has a positive correlation, but currently, the middle-aged perceptions in the Kulim City of Pekanbaru City regarding the prevention effort have not been implemented optimally. The incidence of prediabetes in middle-aged shows quite high numbers. Based on this phenomena, researchers are interested in knowing the middle- aged perception about physical activity in relation to the incidence of prediabetes in the Kulim City of Pekanbaru..

\section{OBJECTIVE}

This study aimed to determine correlation perceptions of middle-aged about physical activity toward incident prediabetes. 


\section{STRADA Jurnal Ilmiah Kesehatan}

DOI: $10.30994 /$ sjik.v8i2.205

\section{METHODS}

This research was using associative quantitative method. Questionnaire was used to find out the pre-diabetes perception of physical activity and examination of fasting blood sugar by glutes tool was used to aware the incidence of prediabetes.

This study applied analytic observational design with cross-sectional method. Sampling was using cluster sampling, where about middle- aged in Kulim City of Pekanbaru were determined as the samples. Collection of data from this study was by using questionnaire. Questionnaires have been conducted ethically with number 156/UN.19.5.1.1.8/UEPKK/2018 and then glutes tools that had licensed by the Ministry of Health.

\section{RESULTS}

Representation of middle age's perception about physical activity

Middle age's perception about physical activity was a categorical data. This perception consist of positive perception and negative perception. The result of this research was representation by frequency distribution and percentage, as shown in the Table 1.1

Table 1. Frequency distribution of middle age's perception about physical activity in Kulim City, Pekanbaru

\begin{tabular}{lll}
\hline Peceptions & Frequncy $(\mathrm{F})$ & Percentage $(\%)$ \\
\hline Negative & 14 & 25,9 \\
Positive & 40 & 74,1 \\
Amount & 54 & 100
\end{tabular}

Table 1. shows that majority of middle aged in Kulim City have a positive perception about $40(74,1 \%)$ for physical activity.

\section{Representation of middle age's prediabetes incident}

Prediabetes incident of middle age was classified into non-prediabetes and prediabetes. The result of the research was representation by frequency distribution and percentage, as shown in the Table 2.

Table 2. Frequency distribution of middle age's prediabetes incident in Kulim City,

Pekanbaru

\begin{tabular}{lll}
\hline Prediabetes incident & Frequency & Persentage $(\%)$ \\
\hline Prediabetes & 16 & 29,6 \\
Non-prediabetes & 38 & 70,4 \\
Quantity & 54 & 100 \\
\hline
\end{tabular}

Table 2 shows that pradiabetes against middle age in Kulim City Pekanbaru was occure only for a small portion of middle age $(29,6 \%)$.

Middle age's perception about physical activity and this relation to prediabetes incident in Kulim City, Pekanbaru

Frequency and percentage of middle age's perception about physical activity and their prediabetes incident was acquired by univariat analysis. This result will be linked with bivariate analysis, where middle age's perception about physical activity's variable related to prediabetes incident. 


\section{STRADA Jurnal Ilmiah Kesehatan}

DOI: $10.30994 /$ sjik.v8i2.205

ISSN: 2252-3847 (print); 2614-350X (online)

Vol.8 No.2. November 2019. Page.101-107

Table 3. Middle age's perception about physical activity and this relation to prediabetes incident in Kulim City, Pekanbaru.

\begin{tabular}{|c|c|c|c|c|c|c|c|c|}
\hline \multirow{3}{*}{ Variable } & \multicolumn{6}{|c|}{ Incident } & \multirow[t]{3}{*}{ OR $(95 \% \mathrm{CI})$} & \multirow[t]{3}{*}{$\mathrm{P}$} \\
\hline & \multicolumn{2}{|c|}{ Non prediabetes } & \multicolumn{2}{|c|}{ Prediabetes } & \multicolumn{2}{|c|}{ Quantity } & & \\
\hline & $\mathrm{N}$ & $\%$ & $\mathrm{~N}$ & $\%$ & $\mathrm{~N}$ & $\%$ & & \\
\hline Perceptions & & & & & & & $\begin{array}{l}0,118 \\
0,461)\end{array}$ & 0,002 \\
\hline Negative & 5 & 35,7 & 9 & 64,3 & 14 & 25,9 & & \\
\hline Positive & 33 & 82,5 & 7 & 17,5 & 40 & 74,1 & & \\
\hline Qunatity & 38 & 70,4 & 16 & 29,6 & 54 & 100 & & \\
\hline
\end{tabular}

Table 3 shows that quantity of middle age with negative perception and non prediabetes was $5(35,7 \%)$ and with prediabetes was $9(64,3 \%)$, however there are $33(82,5 \%)$ middle age with positive perception but non prediabetes and also $7(17,5 \%)$ middle age with prediabetes. Further analysis shown that middle age's perception about physival activity have relation with prediabetes incident $(p=0,002 ; \alpha=0,05)$. Therefore, it can be concluded that there are relation between middle age's perception about physical activity and prediabetes incident in Kulim City Pekanbaru. Besides that, middle age with negative perception about physical activity have 0,118 times higher chance of suffering prediabetes $(\mathrm{OR}=0,118 ; 95 \%$ CI 0,030-0,461).

\section{DISCUSSION}

\section{Prediabetes incident for middle aged in Kulim City, Pekanbaru}

Result of this research shown that middle age's proportion with prediabetes was quite high $(29,6)$. This results was higher than previous research, such as prediabetes in Bogor and Pekanbaru, observed that there were $29,1 \%$ of middle age with prediabetes in Central (Nur Rizky Ramadhani, 2017), has also observed and there were 23,72 \% (Artanti, Masdar, \& Rosdiana, 2015). From 1000 patient, there were 48,5 prediabetes incident (Aljabri, Bokhari, Alshareef, Khan, \& Aljabri, 2018).

A high incidence of prediabetes can be caused by many factor. Nies expressed that along with age, as much $20,7 \%$ middle age have illness condition and it caused glucose levels increase. According to ADA (2012), the decrease in the ammount and effectivity of insulin was the cause of prediabetes. Kontjoro in Aspriani (2014) said that along with age, the metabolism of our body have disturbance like increasing of insulin (diabetes).

This conditions need special concern because prediabetes incident in the middle age can cause another health problems. Soewondo and Pramono (2012) explained that prediabetes condition will have a risk 2-10 times incur diabetes mellitus type 2. Rumahorbo (2015) said that one-third of prediabetes individual will turn into DM type 2. In accordance with those, prediabetes can also increase endothelial disfungsion for women (Fatimah Eliana, Pradana Suwondo, Lukman Hakim Makmun, 2009), and risk of cancer (Y. Y. Huang et al., 2014). Middle aged with prediabetes will evolve become depression (Chen et al., 2016), Prediabetes can also increase risk of cardiovascular (Rumahorbo, 2015), can be increase heart disease (Y. Huang, Cai, Mai, Li, \& Hu, 2016).

From this research, it be expected that there are high awareness from middle age because 


\section{STRADA Jurnal Ilmiah Kesehatan}

DOI: $10.30994 /$ sjik.v8i2.205

ISSN: 2252-3847 (print); 2614-350X (online)

Vol.8 No.2. November 2019. Page.101-107

prediabetes will give bad impact for our body. Based on data in field was acquired that most of middle age simply know diabetes mellitus will harmful when glucose level was at 200 $\mathrm{mg} / \mathrm{dl}$.

Community nurse has not practice his/her job and role optimally. It was reflected from summarize of prediabetes incident that hasn't found. Besides that, program of prediabetes control also hasn't found. This was most likely that nurse's job and role is not optimal. Health education and promotion that implemented continuously will bring positive impact to decrease prediabetes incident and also another infectious illness in middle age.

Researcher explained that community nurse have a big chance in control of prediabetes in Kulim City. There are 3 level of health promotion that be done by community nurse,such as primary, secondary, and tertiary. Health promotion in primary level was done by giving education about prediabetes in detail and community health behavior was expected more effective. In secondary level, community nurse can identify prediabetes risk factor in community. In tertiary level, community nurse capable to consult with special team so prediabetes will not expand to DM type 2. The Policy in here can be opportunities in maintain prediabetes incident.

\section{Middle aged perception about physical activity in Kulim City, Pekanbaru}

Univariate analysis shows that middle aged who have positive perceptions are greater than the negative with the proportion about $74,1 \%$. The emergence of positive perception in middle aged can be caused from many factors. Perception is defined as four parts, a personal process to understands the environment such as organizing and interpretation of stimulating in a psychological experience; a congenitive process, which is interpreting objects, symbols and people with relevant experience; the information extraction process for preparing to respond; perceptions of accepting, choosing, managing, storing, and interpreting stimuli become a whole and meaningful picture of the world (Hidayat, 2010)

Physical activity is a health promotion in improving health (Vuori, 2018). The development of evidence-based prevention programs related to physical activity (Edwards and Hosseinzadeh, 2017). The intensity of physical activity is related to the high incidence of diabetes (Compeán-Ortiz et al., 2018). By doing physical activity can protect sugar levels (Walsh, 2018).

A positive perception of physical activity in predominant majority is seen in the duration and types of physical activity. Possible positive perceptions due to internal and external factors. The internal factor is assumed from the inside of the pralansia is the desire to know about sugar disease both in the form of prevention and problems resulting from the onset of sugar disease. The external factor is assumed that the formation of positive perception in pralansia due to the activeness of community leaders, RT, RW in socializing health activities, besides support from pre-family families also participate actively in the formation of positive perceptions in pralansia.

\section{Middle aged perception about physical activity and its correlation in prediabetes incident in Kulim City, Pekanbaru}

Bivariate test analysis shows that middle-aged perception about physical activity has a correlation with prediabetes incident. It can be seen in $\mathrm{P}$ value, about 0,002 . Individuals who believe that they have a low risk of disease will be more likely to do unhealthy actions, and otherwise, they will do healthy behavioaral to reduce the risk of developing the disease (Onoruoiza et al., 2015). 


\section{STRADA Jurnal Ilmiah Kesehatan}

DOI: $10.30994 /$ sjik.v8i2.205

ISSN: 2252-3847 (print); 2614-350X (online)

Vol.8 No.2. November 2019. Page.101-107

This research is align with the research in Koplak Grobogan localization, that the lower the perception of a person's vulnerability, the lower the effort to prevent disease and vice versa (Widodo, 2009). It reinforces that middle-aged perception about physical activity has a correlation with prediabetes incident.

Individual's health status is influenced by several factors, including development, sociocultural, past experiences, one's expectations about himself, heredity, environment, and health services (Budi \& Pertami, 2015). Environmental and behavioral factors have a major contribution in health levels, $45 \%$ environmental factor is estimated and $30 \%$ behavioral factors (Bloom, in Kozier, et al, 2011). Individual health is influenced by behavior by $50 \%$ (CDC 2006; Bremer \& Synder, 2014).

The result of research showed that middle-aged who had negative perceptions had a 0.118 times chance of being exposed to prediabetes compared with middle-aged who had a positive perception. The researchers suggests that the cause of the lack of opportunities in middle aged who have negative perceptions about physical activity is caused by behavioral factors. This study has a similiarity that individual health is influenced by behavior by $50 \%$ (CDC 2006; Bremer \& Synder, 2014). Middle aged has understood that the disease can be prevented, such as by doing easy exercise. Middle aged also has a high sense of care for disease prevention, but there is a little of middle aged that could not practice in daily life, for example creating a sports schedule that can be done continuously. It cause the middle aged exposed to prediabetes. Subsequent analysis, as positive perceptions of physical activity, then efforts to prevent the emergence of middle aged problems can be controlled, especially in the incidence of prediabetes.

\section{CONCLUSION}

Based on the results and discussion of research in Kulim City, Pekanbaru City, it can be concluded that Pralansia has a positive perception of physical activity of 40 (74.1\%). The incidence of prediabetes in pralysis is $16(29.6 \%)$. There is a correlation between prediabetes perception of physical activity and the incidence of prediabetes ( $p$ value 0,002 ).

It is expected to know in depth about prediabetes in middle aged. They should understand that preventive measure is positively has a correlation to a decrease in the incidence and prevalence of prediabetes in the Kulim City of Pekanbaru. Middle aged is able to practice physical activity continuously.

Community Services are expected to immediately improve the quality of nurses. This quality improvement for example by attending workshops, trainings, nurse exchanges across provinces, countries and changing the design of health promotion for the community such as group discussion forums, audi visuals. The existence of good quality will be reflected in the decrease in the incidence of prediabetes so that the degree of health and maintenance can be achieved. In addition, the provision of pre-insurance post-service in breaking the chain of non-communicable diseases is needed.

For the development of nursing science, it is expected that the link between physical activity and the incidence of prediabetes can be used as a source in the development of nursing. Especially gerontik and community for nurses and students. 


\section{REFERENCES}

Aljabri, K. S., Bokhari, S. A., Alshareef, M. A., Khan, P. M., \& Aljabri, B. K. (2018). Associated Risk Factors in Pre-diabetes and Type 2 Diabetes in Saudi Community, 1(2), 1-7.

Artanti, P., Masdar, H., \& Rosdiana, D. (2015). “Angka kejadian diabetes melitus tidak terdiagnosis pada masyarakat kota pekan baru.” Jom FK, Vol 2 No.(9), 1689-1699. https://doi.org/10.1017/CBO9781107415324.004

Care, D. (2014). Diagnosis and classification of diabetes mellitus. Diabetes Care, 37 Suppl 1(Supplement 1), S81-S90. https://doi.org/10.2337/dc10-S062

Chen, S., Zhang, Q., Dai, G., Hu, J., Zhu, C., Su, L., \& Wu, X. (2016). Association of depression with pre-diabetes, undiagnosed diabetes, and previously diagnosed diabetes : a meta-analysis . Endorine, 53(1), 35-46. https://doi.org/10.1007/s12020016-0869-x.

Fatimah Eliana, Pradana Suwondo, Lukman Hakim Makmun, D. S. H. (2009). No Title. JURNAL KEDOKTERAN YARSI, 17(3), 2009.

Huang, Y., Cai, X., Mai, W., Li, M., \& Hu, Y. (2016). CCBYNC Open access Research. Thebmj, 20-21.

Huang, Y. Y., Cai, X., Qiu, M., Chen, P., Tang, H., Hu, Y., \& Huang, Y. Y. (2014). Prediabetes and the risk of cancer: a meta-analysis. Diabetologia, 57(11), 22612269. https://doi.org/10.1007/s00125-014-3361-2

Nur Rizky Ramadhani, N. A. (2017). OBESITAS UMUM BERDASARKAN INDEKS MASA TUBUH DAN OBESITAS ABDOMINAL BERDASARKAN LINGKAR PINGGANG TERHADAP KEJADIAN PREDIABETES. Jurnal Ilmiah Kesehatan, 16(3), 1-12.

Of, S., \& Carediabetes, M. (2015). STANDARDS OF MEDICAL CARE, 38(January).

Panesar, K., \& Hons, B. (2013). Prediabetes Management. US Pharm. 2013;38(10)(Diabetes Suppl):, 38(10), 11-17.

Pradana Soewondo, L. A. P. (2011). Prevalence, characteristics, and predictors of prediabetes in Indonesia. Medical Journal of Indoneisa, 20(4).

Ramachandran, A. (2012). Trends in prevalence of diabetes in Asian countries. World Journal of Diabetes, 3(6), 110. https://doi.org/10.4239/wjd.v3.i6.110

Sovia, Rekawati, E., \& Kuntarti. (2013). Kejadian Pradiabetes Pada Usia Dewasa Menengah Berdasarkan Karakteristik Dan Perilaku Perawatan Kesehatan Keluarga. Jurnal Keperawatan Indonesia, 16(3), 145-153. https://doi.org/10.7454/jki.v16i3.325145-153

Vuori, I. (2018). World Health Organization and Physical activity. Progress in Preventive Medicine, 3(1). https://doi.org/10.1097/pp9.0000000000000012

Walsh, E. I. (2018). Physical Activity and Blood Glucose Effects on Weight Gain Over 12 Years in Middle-Aged Adults. Journal of Obesity and Chronic Diseases, 2(1), 2025 